\title{
PENERAPAN MATERI DERADIKALISASI \\ UNTUK MENANGGULANGI RADIKALISME \\ PADA EKSTRAKURIKULER KEAGAMAAN \\ (Penelitian Tindakan pada Ekstrakurikuler Keagamaan DKM Nurul Khomsah di SMA Negeri 5 Bandung)
}

\author{
Panji Futuh Rahman, ${ }^{*}$ \\ Endis Firdaus, Wawan Hermawan \\ Program Studi Ilmu Pendidikan Agama Islam, \\ Fakultas Pendidikan Ilmu Pengetahuan Sosial, Universitas Pendidikan Indonesia \\ *Email: panji.futuh@student.upi.edu
}

\begin{abstract}
ABSTRAK
Penelitian ini merupakan penelitian tindakan yang bertujuan melihat hasil penerapan materi deradikalisasi untuk menanggulangi radikalisme pada ekstrakurikuler keagamaan. Penelitian ini dilatarbelakangi maraknya aksi teror serta kekerasan atas nama agama. Sejauh ini, pemerintah dalam menanggapi radikalisme maupun terorisme tersebut lebih banyak berfokus pada penanggulangan pasca teror seperti rehabilitasi pelaku teror serta pelatihan-pelatihan untuk dosen dan pimpinan kampus untuk mengantisipasi radikal dan terorisme. Namun, belum ada tindakan baik yang bersifat preventif maupun deradikalitatif terhadap penyebaran radikalisme dikalangan anak muda, khususnya SMA. Padahal remaja usia belasan tahun adalah sasaran empuk penyebaran radikalisme ini. Maka dari itu penelitian tindakan ini bertujuan menerapkan materi deradikalisasi untuk menanggulangi radikalisme pada ekstrakurikuler keagamaan. Penelitian tindakan ini melalui 2 siklus dengan masing-masing siklus terdapat 2 tindakan dan untuk mengukur tingkat radikalisme tersebut digunakan angket. Hasil penelitian tindakan ini menunjukkan bahwa penerapan materi deradikalisasi dapat menanggulangi radikalisme pada ekstrakurikuler keagamaan. Disamping itu, penelitian ini juga bermanfaat untuk diterapkan menjadi upaya antisipasi penyebaran radikalisme di kalangan siswa SMA.
\end{abstract}

Kata Kunci: Deradikalisasi, Ekstrakurikuler, Radikalisme. 


\section{PENDAHULUAN}

Jika dirincikan, sejak tahun 2000 menurut Irjen Polisi (purn) Ansyaad Mbay Indonesia telah beberapa kali menjadi sasaran serangan terorisme, mulai dari bom Natal (2000), disusul kemudian bom Bali I (2002), bom JW Marriott (2003), bom Kedubes Australia (2004), bom Bali II (2005) dan bom Marriott dan Ritz Carlton (2009) (dalam Hikam, 2015, hlm. 25).

Terorisme sendiri menurut Jones adalah tindakan ilegal dan radikal yang dilakukan oleh aktor non-negara, baik individu maupun kelompok untuk tujuan politis, ekonomi, dan sosial melalui penyerangan secara acak (dalam Hikam, 2015, hlm. 24).

Terorisme sangat mungkin tumbuh dalam lingkungan yang subur yang menurut Hendropriyono dalam Bakti (2015, hlm. 9) lahan subur itu adalah masyarakat yang dicemari oleh paham fundamentalisme ekstrim dan radikalisme keagamaan.

Endang Turmudi mengatakan bahwa radikalisme sangat berkaitan dengan fundamentalisme, yang ditandai oleh kembalinya masyarakat kepada dasardasar agama. Fundamentalisme akan diiringi radikalisme dan kekerasan apabila kebebasan untuk kembali kepada agama dihalangi oleh situasi sosial politik yang mengelilingi masyarakat dalam (Suprihatiningsih, 2012, hlm. 369).

Disampaikan Lazuardi Birru dalam (Bakti, 2015 hlm. 9) bahwa Radikalisme sendiri dipengaruhi beberapa hal, antara lain; pemahaman Islam yang cenderung legalistik dan ekslusif, penghargaan terhadap kelompok minoritas yang rendah, perasaaan terasing dari kehidupan kolektif (merasa umat Islam dipojokan), dan hadirnya organisasi-organisasi gerakan radikal.

Hal ini tentu sangat meresahkan, terlebih jika mengingat bahwa salah satu upaya penyebaran paham radikal adalah melalui pembinaan Rohis di SMP/SMA yang disusupi yang tidak lain anggotanya adalah kalangan muda (Munip, 2012, hlm. 167).

Belum lagi ditambah penyebaran radikalisme di dunia maya yang makin gencar. Gabriel Weimann menyebutkan bahwa jika pada tahun 1998 hanya ada 12 situs yang dimiliki kelompok teroris, pada tahun 2003 situs kelompok terosis ini sudah mencapai 2.650. Maka di tahun 2014 telah terdapat lebih dari 9.800 situs yang dimiliki oleh kelompok terorisme dalam (Bakti, 2015, hlm. 12). Karena, selain melalui media cetak, kelompok radikal juga memanfaatkan dunia maya untuk menyebarluaskan buku-buku dan informasi tentang jihad (Munip, 2012, hlm. 171).

Meski secara etimologi, kata radikal sebenarnya bermakna positif. Kini pemahaman tentang kata radikal sudah melenceng. Yusuf Qardhawi (2009, hlm. 35) misalnya membagi terma radikal kedalam dua jenis. Yakni radikal kiri dan radikal kanan. Hanya saja, menurutnya kini kedua terma tersebut menjadi bias dan diartikan semaunya saja.

Sedangkan menurut Muhamad, (2013, hlm. 63) Islam radikal adalah aliran dalam Islam yang mencita-citakan terlaksananya syariah Islam dalam kehidupan sosial politik dan untuk mencapai cita-cita itu dilaksanakan tindakan-tindakan kekerasan dan drastis. Kekerasan untuk mencapai cita-cita tegaknya syariah itu kadang mereka anggap sebagai jihad (Suprihatiningsih, 2012, hlm. 372)

Dalam Modul BNPT terkait penanggulangan radikalisme dan terorisme di sebutkan bahwa secara sederhana indikasi radikalisme dapat diukur melalui beberapa wacana seperti: ketaatan sebagai warga negara, kesetiaan pada Pancasila, keinginan mendirikan negara Islam, dukungan untuk hukum syariat, aksi kekerasan juga Jihad (Kuba dkk., 2014, hlm. 18).

Radikalisme sendiri dapat ditandai dengan beberapa indikator radikal 
sebagaimana disampaikan Qardhawi (2009, hlm. 40-55) Pertama adalah fanatisme terhadap satu pendapat tanpa mengakui adanya pendapat lain, mewajibkan orang lain untuk melaksanakan apa yang tidak diwajibkan oleh Allāh Swt., sikap keras dan kasar yang terkadang tidak pada tempatnya, berprasangka buruk terhadap orang lain dan Radikalisme ini mencapai puncaknya ketika mulai mengafirkan dan menuduh manusia lain sudah murtad dari islam.

Penyebab kemunculan gerakan radikal bukan hanya disebabkan oleh kegelisahan kaum agamawan terhadap pembebasan pemahaman-pemahaman terhadap ajaran-ajaran keagamaan saja. Tapi juga dipengaruhi oleh keadaan politik kekuasaan, ekonomi, dan kebudayaan terhadap gerakan radikal juga sangat kuat (Hibban, 2014, hlm. 251).

Abdullah Saeed juga

memandangnya sebagai respons terhadap kolonialisme, hegemoni dan dominasi barat, serta politik standar ganda yang diterapkan oleh Barat seperti pembatasan dakwah Islam namun dukungan terhadap kalangan missionaris (dalam Burhani, 2001, hlm. 434).

Berkenaan dengan upaya penanggulangannya, Qardhawi (2009, hlm. 132) mengimbau agar memperlakukan mereka (kaum radikalise) dengan jiwa kebapakan yang penuh kasih sayang, persaudaraan dan cinta, mengesankan bahwa mereka adalah bagian dari kita.

Disamping itu, Qardhawi (2009, hlm. 140) melanjutkan bahwa harus menyebarkan udara kebebasan, menerima kritik dengan lapang dada, dan menghidupkan semangat saling menasehati dalam agama. Menurutnya radikalisme ini bersumber dari pikiran. Oleh karenanya, ia harus mendapat terapi pemikiran pula.

Memang benar, bahwa salah satu dari upaya penanggulangannya adalah dengan mengedepankan dialog, ini senada dengan pandangan di atas bahwa dengan Dialog, pada gilirannya, akan menggiring pemeluk agama pada sifat yang inklusif dan menghargai perbedaan (Munip, 2012, hlm. 177).

Misi ajaran Islam yang sebenarnya sangat mulia dan luhur itu seringkali justru mengalami distorsi akibat pamahaman yang keliru terhadap beberapa aspek ajaran Islam yang berpotensi menimbulkan radikalisme (Munip, 2012, hlm. 174). Maka dari itu, memahami persoalan agama secara komprehensif menjadi salah satu upaya penanggulangan radikalisme ini.

Qardhawi (2009, hlm. 148) menyebutkan bahwa pengetahuan syariat ini tidak bisa terwujud dengan sempurna hanya dengan mengetahui naș-naș nya secara parsial, terpisah dan berceceran, yang satu terlepas dari yang lain. akan tetapi, persoalan-persoalan parsial dikembalikan kepada yang bersifat makro, yang mutasyābih dikembalikan kepada yang muhkam, yang bersifat dugaan dikembalikan kepada yang qaț' 1 , sehingga akan terbentuk satu jalinan yang kuat antara satu dengan yang lain.

Lepas dari itu semua, untuk penanggulangannya di sekolah, Munip (2012, hlm. 177) menyebutkan salah satu upaya untuk penanggulangannya adalah memberikan penjelasan terkait hakikat jihad, toleransi dan hubungan ajaran Islam dengan kearifan budaya lokal serta pengenalan dan penerapan pendidikan multikultural.

Lebih lanjut, Qardhawi (2009, hlm. 155) mengatakan bahwa salah satu yang diabaikan oleh orang-orang beragama adalah pengetahuan tentang tingkatantingkatan hukum syariat Karena sesungguhnya hukum syariat tidak memiliki kedudukan yang sama, baik dari segi kepastiannya maupun dalam hal kebolehan berbeda pendapat mengenainya.

Maka dapat disimpulkan mengenai pemahaman yang perlu diluruskan, sebagaimana sudah dipaparkan pula sebelumnya, merupakan hal-hal yang menjadi dasar bagi pemahaman keislaman dan harus disampaikan dengan teliti untuk menanggulangi radikalisme. Adapun 
materinya antara lain: pemahaman tentang, sistem hukum Islam, ilmu tafsir, konsep Khilāfah, dan konsep jihad.

\section{METODE}

Penelitian ini merupakan penelitian tindakan atau disebut juga action research. Tomal (2003, hlm. 5) menjelaskan Action research sebagai "a systematic process of solving educational problems and making improvements". Atau dapat diartikan bahwa penelitian tindakan adalah sebuah proses yang sistematis untuk menyelesaikan permasalahanpermasalahan pendidikan dan membuat perbaikan-perbaikan

Desain penelitian ini menggunakan model daur siklus yang dikembangkan oleh Kemmis dan Mc Taggart. Menurut Arikunto (2006, hlm. 97), "Model ini mencakup empat komponen, yaitu: rencana (planning), tindakan (action), observasi (observation) dan refleksi (reflection)". Untuk melihat dengan jelas seperti apa metode penelitian yang digunakan berdasarkan daur siklus. Penjalelasan dari tiap tahapannya adalah sebagai berikut:

\section{Perencanaan}

Dalam tahap ini disusun rencana pembelajaran untuk menerapkan materi deradikalisasi di kajian keagamaan peneliti menjelaskan tentang apa, mengapa, kapan, dimana, oleh siapa, dan bagaimana tindakan tersebut akan dilakukan. Penelitian tindakan dilakukan secara berpasangan antara pihak yang melakukan tindakan dan pihak yang mengamati proses jalannya tindakan (observer).

\section{Tindakan}

Tahap ke-2 dari penelitian tindakan adalah pelaksanaan yang merupakan implementasi atau penerapan isi rancangan, yaitu mengenai tindakan kelas. Pada tahap ini, pelaksana atau guru melaksakan kegiatan tindakan peneltian sesuai dengan rancangan perencanaan yang sudah disusun sebelumnya. Pada tiap tindakan ditetapkan skenario tindakan dan dilaksanakan dalam situasi yang aktual. Kegiatan pebukaan dilakukan selama 10 menit lalu kegiatan inti berlangsung selama 65 menit sedangkan kegiatan penutup berlangsung selama 15 menit.

\section{Pengamatan}

Tahap ke-3, yaitu kegiatan pengamatan yang dilakukan oleh observer. Pengamatan dilakukan pada waktu tindakan pelaksanaan pembelajaran sedang dilakukan dan kegiatan pengamatan dilakukan oleh observer, bukan peneliti langsung. Sehingga, keduanya bisa dilakukan secara bersamaan. Pengamatan bertujuan melihat keberlangsungan kegiatan pembelajaran serta hal-hal yang terjadi dan dianggap penting dalam penelitian yang dilakukan.

\section{Refleksi}

Tahap ke-4 merupakan kegiatan untuk mengemukakan kembali apa yang sudah dilakukan. Kegiatan refleksi dilakukan ketika sudah selesai melakukan tindakan pelaksanaan pembelajaran, kemudian berhadapan dengan observer untuk mendiskusikan implementasi rancangan tindakan. Hal-hal yang direfleksikan adalah tingkat radikalisme siswa melalui angket radikalisme yang disebarkan setelah siklus selesai, keberlangsungan kegiatan serta hal-hal yang harus diperbaikai maupun masukan untuk kelancaran kegiatan, hasil observasi guru untuk melihat kesesuaian antara pelaksanaan dengan perencanaan yang sebelumnya disusun.

Penelitian ini dilakukan di Sekolah Menengah Akhir Negeri (SMAN) 5 Kota Bandung yang bertempat di jalan Belitung no. 8 Kecamatan Sumur Bandung Kota Bandung. Dalam penelitian ini, yang menjadi populasi penelitian adalah siswa anggota ekstrakurikuler keagaman DKM Nurul Khomsah. Disamping itu, dalam penlitian ini akan terlibat pula partisipan penlitian. Wiratha (2006, hlm. 35) menyebutnya sebagai sumber data penelitian. Adapun partisipan dalam kegiatan penelitian ini adalah pembina ekstrakurikuler tersebut yang tidak lain 
merupakan guru PAI dan BP di SMA Negeri 5 Bandung, ibu Rahmawati.

Dalam penelitian tindakan ini, instrument yang bisa digunakan untuk mengumpulkan data tersebut adalah survei menggunakan angket. Dan angket yang digunakan adalah angket satu arah yang berisikan pertanyaan tertutup.

Sedangkan untuk analisis data dalam penelitian ini menggunakan pengolahan statistik sederhana untuk mengukur rata-rata dan melakukan perbandingan tingkat radikalisme saat pretest, setelah siklus 1 dan setelah siklus 2. Hal ini dilakukan untuk melihat perubahan tingkat radikalsime siswa baik secara keseluruhan, rata-rata dan juga melihat perubahan tingkat radikalisme ditiap indikator.

\section{HASIL DAN PEMBAHASAN}

Penelitian ini dilaksanakan di SMA Negeri 5 Bandung pada semester genap Tahun Pelajaran 2015/2016 dengan subjek penelian siswa anggota ekstrakurikuler keagamaan di SMA Negeri 5 Bandung yakni DKM Nurul Khomsah. Jumlah keseluruhan anggota ekstrakurikuler ini sendiri mencapai 112 orang siswa yang berasal dari siswa kelas X dan XI. Namun pada penelitian ini yang dilibatkan adalah siswa anggota ekstrakurikuler keagamaan yang merupakan siswa kelas XI. Jumlah siswa anggota ekstrakurikuler ini yang merupakan kelas XI mencapai 54 orang siswa yang terdiri atas, 33 orang siswa dan 21 orang siswi.

Sebelum melakukan tindakan, peneliti mengukur terlebih dahulu tingkat radikalisme siswa yang mengikuti kegiatan ekstrakurikuler keagamaan ini, hal ini bertujuan untuk melihat tingkat radikalisme siswa yang mengikuti esktrakurikuler keagamaan DKN Nurul Khomsah SMA Negeri 5 Bandung ini. Hasil dari pengukuran angket radikalisme sendiri sebagaimana dalam Grafik 1. dapat dilihat bahwa hasil pengukuran menunjukan tingkat radikalisme siswa yang mengikuti ekstrakurikuler keagamaan dalam kategori tinggi.

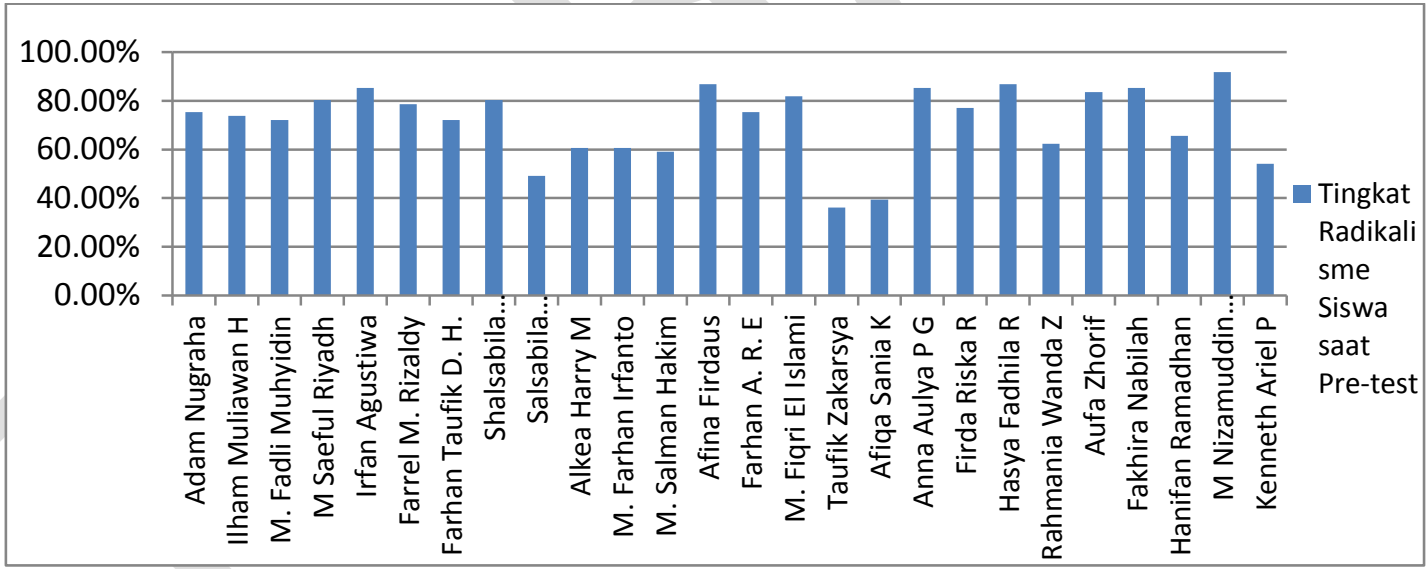

Grafik 1. Tingkat Radikalisme Siswa saat Pre-test.

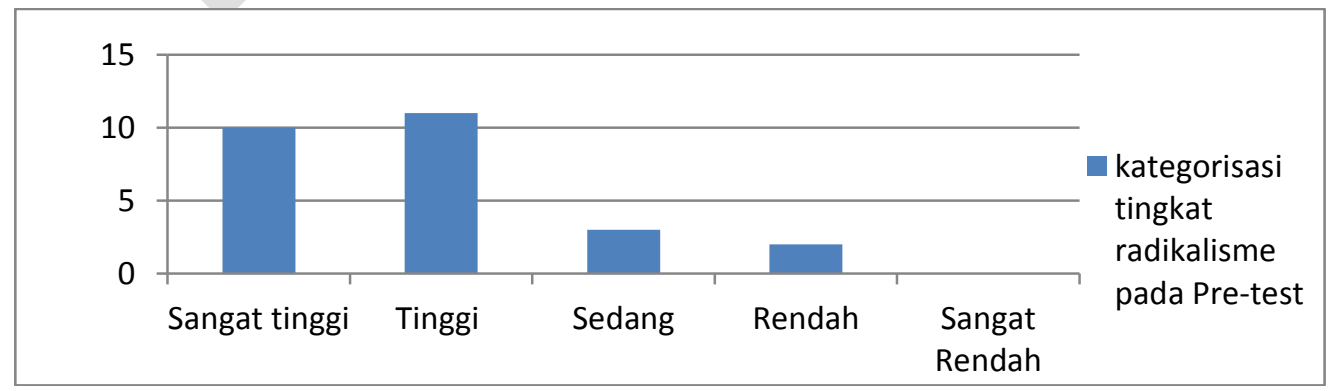

Grafik 2. Kategorisasi tingkat Radikalisme Siswa saat Pretest. 


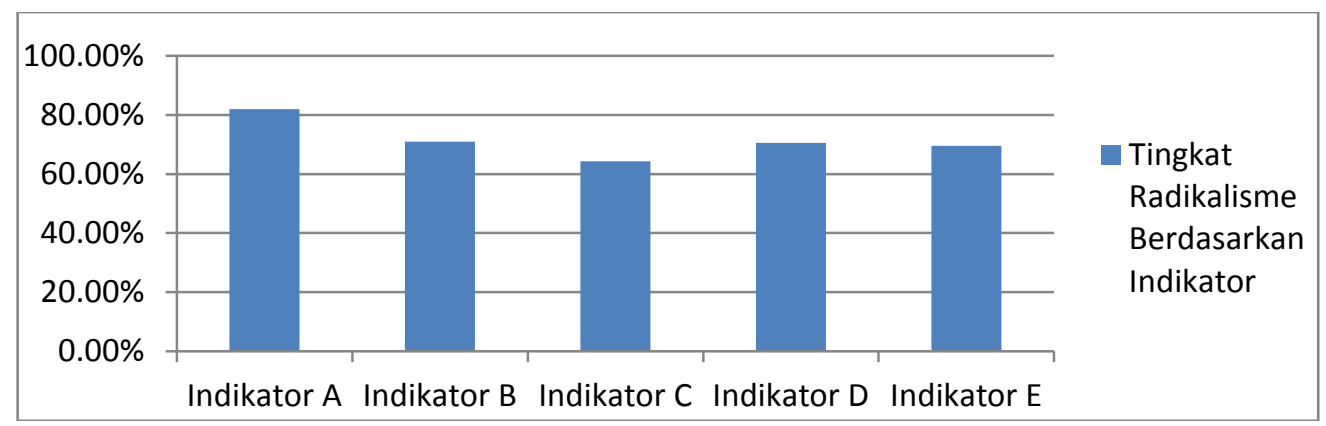

Grafik 3. Tingkat Radikalisme Siswa Berdasarkan Indikator saat Pretest.

Berdasarkan grafik 1. Tingkat radikalisme siswa saat pretest, terdapat 10 orang siswa yang tingkat radikalismenya sangat tinggi, 11 orang siswa lainnya dengan tingkat radikalisme tinggi, 3 orang siswa lainnya dengan tingkat radikalisme sedang, dan terdapat 2 orang siswa dengan tingkat radikalisme rendah serta tidak ada siswa dengan tingkat radikalisme sangat rendah.

Hasil lain dari pengukuran tingkat radikalsime ini adalah data berkenaan indikator yang mencirikan indikasi radikalsime dikalangan siswa. Indikatorindikator tersebut antara lain sikap yang fanatis terhadap satu pendapat atau golongan, mewajibkan orang lain untuk melakukan yang tidak wajib, sikap keras yang tidak pada tempatnya dan kasar, senantiasa berprasangka buruk pada umat agama lain juga muslim lain serta mengafirkan/ menggugurkan kesucian orang lain. Pada pengukuran prasiklus dalam penelitin ini dapat dilihat kondisi radikalisme berdaskan indikatorindikatornya sebagiamana ditunjukkan Grafik 3. Indikator fanatisme terhadap pendapat menunjukkan indikator yang paling tinggi dalam pengukuran radikalisme siswa saat pretest ini dengan angka $81,92 \%$, lalu indikator mewajibkan yang tidak wajib mengindikasikan $71 \%$ begitupun halnya dengan indikator berprasangka buruk dengan 70,5 \% . Sementara untuk sikap keras yang bukan pada tempatnya mengindikasikan 64,3\% dan terakhir indikator mengafirkan orang lain menyumbang 69,6 \% radikalisme siswa pada saat pretest.
Setelah data awal didapat, maka perencanaan penelitian tindakan pun disusun, untuk menyusun materi deradikalisasi. Dalam hal ini, pemahaman mengenai konsep-konsep yang pokok dalam islam menjadi hal mendasar yang harus dipahami siswa agar pemahaman keagamaannya proporsional, hal ini sebagaiana dikatakan Qardhawi (2009, hlm. 76) bahwa kesamaran dalam memahami Islam dan ketidakjelasan dalam melihat prinsip-prinsip syariahnya serta maksudmaksud risalah. Hal bisa mengakibatkan konsep keislaman menjadi rancu dan membingungkan dikalangan pemuda, sehingga Islam dipahami secara tidak proporsional.

Ketidak proporsionalan dalam pemahaman keagamaan tersebut bisa berimbas pada rancunya konsep-konsep keagamaan seperti dikatakan Qardhawi (2009, hlm. 72) bahwa sebagai implikasi dari dangkalnya pengetahuan mereka terhadap agama adalah mereka selalu menyudutkan, bersikap keras dan berlebihlebihan dalam mengharamkan dan memeprluas ruang lingkup hal-hal yang diharamkan.

Azyumardi Azra menyebutkan bahwa salah satu sumber radikalisme adalah pemahaman keagamaan yang literal. Memahami sepotong-sepotong ayat-ayat Alquran (dalam Munip, 2012, hlm. 162). Dapat pula dairtikan hal tersebut sebagai ketidakpahaman terhadap ilmu tafsir.

Disamping itu pula, yang menjadi ciri radikalisme adalah mengafirkan muslim lain. Dalam hal ini istilah kafir sangat sering digunakan umat muslim secara keliru. Padahal radikalisme ini 
mencapai puncaknya menurut Qardhawi (2009, hlm. 55) ketika menggugurkan kesucian orang lain serta menghalalkan darah dan harta mereka. Hal ini terjadi tatkala radikalisme memasuki gelombang pengafiran dan tindakan menuduh kebanyakan manusia telah murtad dari Islam.

Materi deradikalisasi kemudian dikelompokan menjadi dua pembahasan utama dan dibagi berdasarkan siklus, pada siklus 1 materi deradikalisasi mengenai sistem hukum islam dan tafsir sedangkan pada siklus 2 materi khilâfaћ dan jihad. Adapun untuk siklus pertama materi yang disampaikan pada tindakan pertama adalah sistem hukum Islam.

Pada hari pertama penerapan materi deradikalisasi di ekstrakurikuler DKM Nurul Khomsah, anak-anak terlihat antusias dengan materi yang disampaikan mengenai sistem hukum dalam Islam.

Sedangkan pada tindakan 2 dalam siklus 1 disusun perencanaan berdasarkan hasil refleksi pada tindakan sebelumnya yakni dengan menambahkan materi etika dalam berbeda pendapat dan berdebat disamping materi yang sebelumnya sudah disusun yakni mengenai metode penafsiran. Materi-materi ini kemudian disampaikan pada siswa anggota ekstrakurikuler dalama kajian keagmaan.
Setelah dilakukannya tindakan penelitian pada siklus 1 sebagaimana dalam Grafik 4. Menunjukkan hasil bahwa tingkat radikalisme siswa menurun dibandingkan sebelumnya. Pada pengukuran setelah siklus 1 ini didapati bahwa sudah tidak ada lagi siswa dengan tingkat radikalisme sangat tinggi. Namun masih terdapat 5 orang siswa dengan tingkat radikalisme tinggi, sedangkan unutk kategori sedang terdapat 16 orang siswa dan untuk kategori tingkat radikalisme rendah kini terdapat 5 orang siswa. Hal ini dapat dilihat pada grafik 5.

Jika dilihat berdasarkan indikatornya, maka terdapat penurunan tingkat raidkalisme yang signifikan pada semua indikator radikalsime tersebut. Sebagaimana dapat dilihat pada Grafik 6 . Indikator fanatisme terhadap pendapat menunjukkan angka 50,78\%, sedangkan untuk indikator mewajibkan muslim kepada hal yang tidak wajib menunjukkan angaka $36,67 \%$, yang masih tinggi adalah Indikator sikap keras yag tidak pada tempatnya dan kasar dengan tingkat radikalisme $62,637 \%$, dan indikator berprasangka buruk dengan 68,803\%, sedangkan indikator mengafirkan dan menggugurkan kesucian orang lain menunjukkan angka 45,355\%.

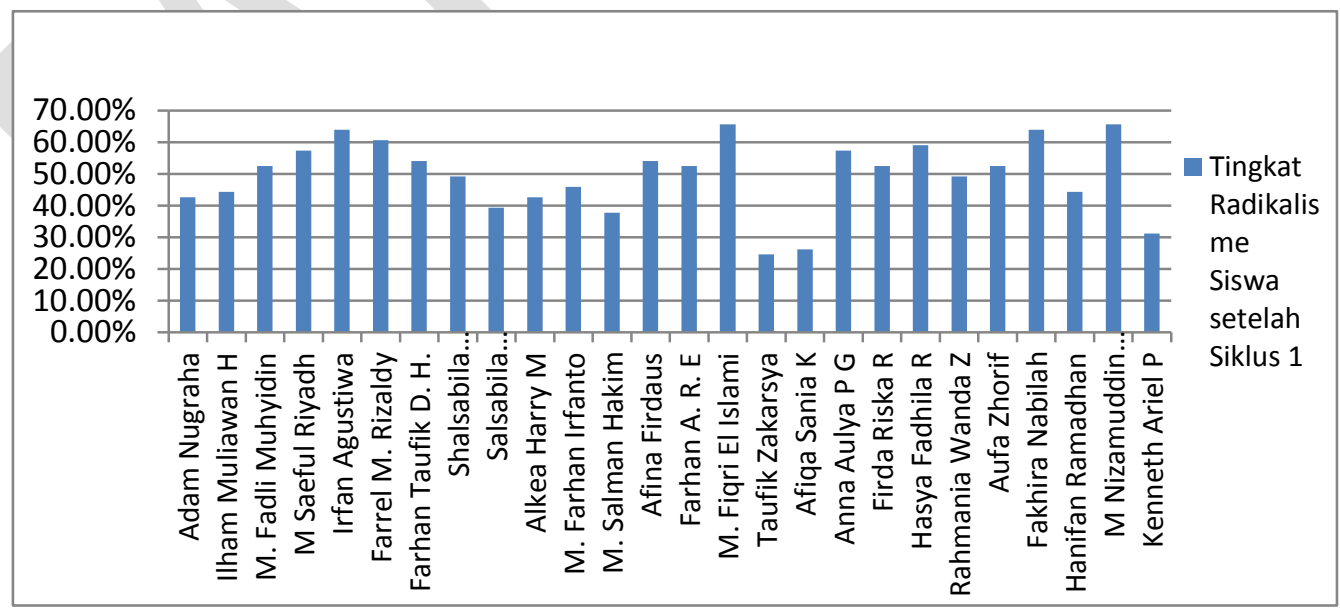

Grafik 4. Tingkat Radikalisme Siswa setelah dilakukan Siklus 1. 


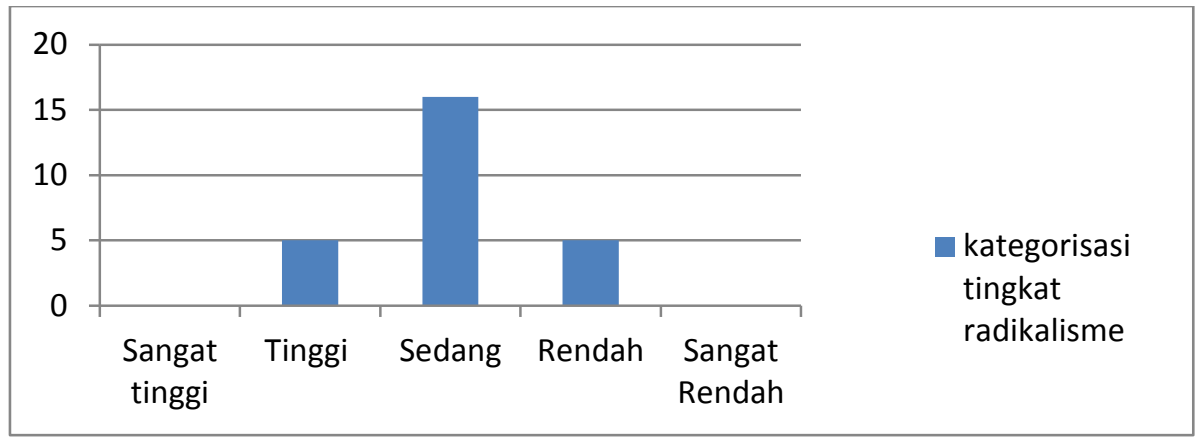

Grafik 5. Kategorisasi tingkat Radikalisme Siswa setelah Siklus 1.

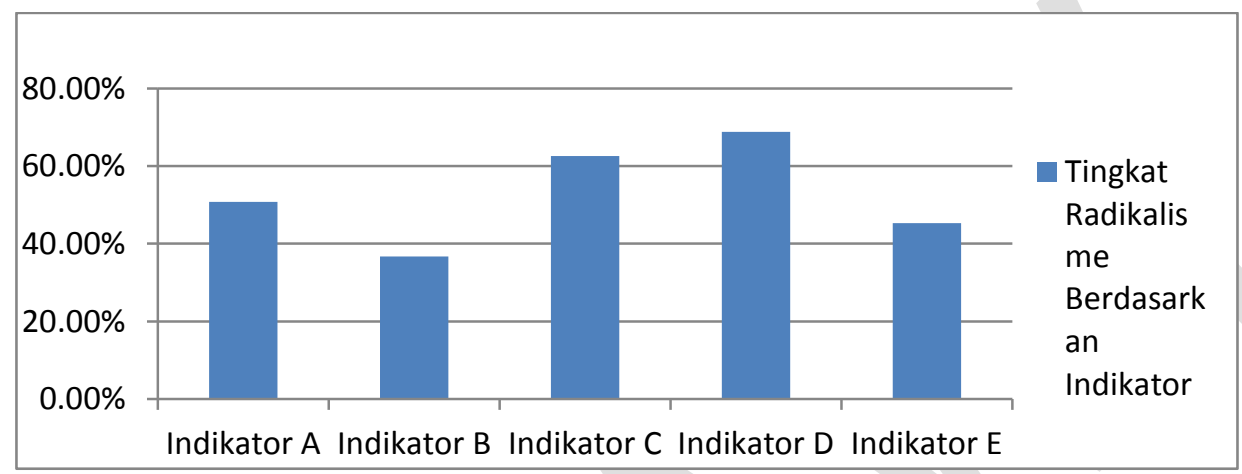

Grafik 6. Tingkat Radikalisme Siswa Berdasarkan Indikator setelah Siklus 1.

Perubahan pada tingkat radikalisme siswa sudah menunjukkan hasil yang positif namun belum mencapai target dalam penelitian ini yakni untuk menjadikan siswa-siswa yang tidak radikal. Maka masih dibutuhkan tindakan pada siklus 2 untuk menerapkan materi deradiklasasi lainnya yakni materi berkenaan kosep jihad dan konsep pemerintahan khilâfaћ.

Maka dari itu, dilakukanlah penelitian pada siklus kedua dengan materi berkenaan khilafah dan jihad. Pada siklus kedua tindakan 1 didahulukan materi berkaitan khilafah. Serta ditambah materi berkenaan amar ma'rûf dan nahyî munkar. Hal ini ditujukan agar siswa memiliki pengetahuan yang benar mengenai hakikat dari amar amar ma'rûf dan nahyî munkar. terutama hal yang berkenaan dengan etika saat menyampaikan kebaikan itu sendiri.

Pada tindakan kedua siklus 2 disampiakan materi berkenaan jihad serta ditambah dnegan materi berkenaan cinta tanah air. hal ini didasari karena kerancuan konsep yang paling mendasar dan hampir selalu ditemui dalam kelompok-kelompok radikal ini salah satunya menurut Muhklis (2012, hlm. 5) adalah terkait jihad atau deklarasi perang suci. Di sini agama tampak menjadi sebuah ancaman tatkala jihad atau deklarasi perang suci menempatkan pihak-pihak tertentu baik yang ekstern (di luar agama anutan pelaku) maupun intern (golongan atau kelompok lain dalam agama anutan pelaku) sebagai musuh yang harus dibinasakan setiap ada peluang dan kesempatan (Mukhlis, 2012, hlm. 5).

Setelah dilakukan penelitian tindakan sebanyak 2 siklus dengan masing-masing siklus terdapat dua tindakan, peneliti membagikan kembali angket radikalisme, hal ini bertujuan mengukur tingkat radikalisme setelah dilakukan nya penelitian.

Hasil pengukuran tingkat tradikalsiem menunjukkan bahwa tingkat radikalisme semua siswa anggota ekstrakurikuler dari tahap ke tehap penelitian dimulai dari pengukuran radikalisme saat pre-test, pengukuran radikalisme setelah dilakukannya siklus 1 hingga pengukuran radikalisme setelah 
dilaksanakannya siklus 2 selalu menunjukkan penurunan. Dari data hasil pengukuran tersebut dapat dilihat pada Grafik 7. Bahwa tingkat radikalisme tiap siswa menurun dari sejak pretest, siklus 1 hingga setelah siklus dua. Hingga di pengukuran radikalisme pada akhir siklus 2 sudah tidak ada lagi siswa dengan tingkat radikalisme tinggi dan umumnya berada pada tingkat radikalisme rendah.

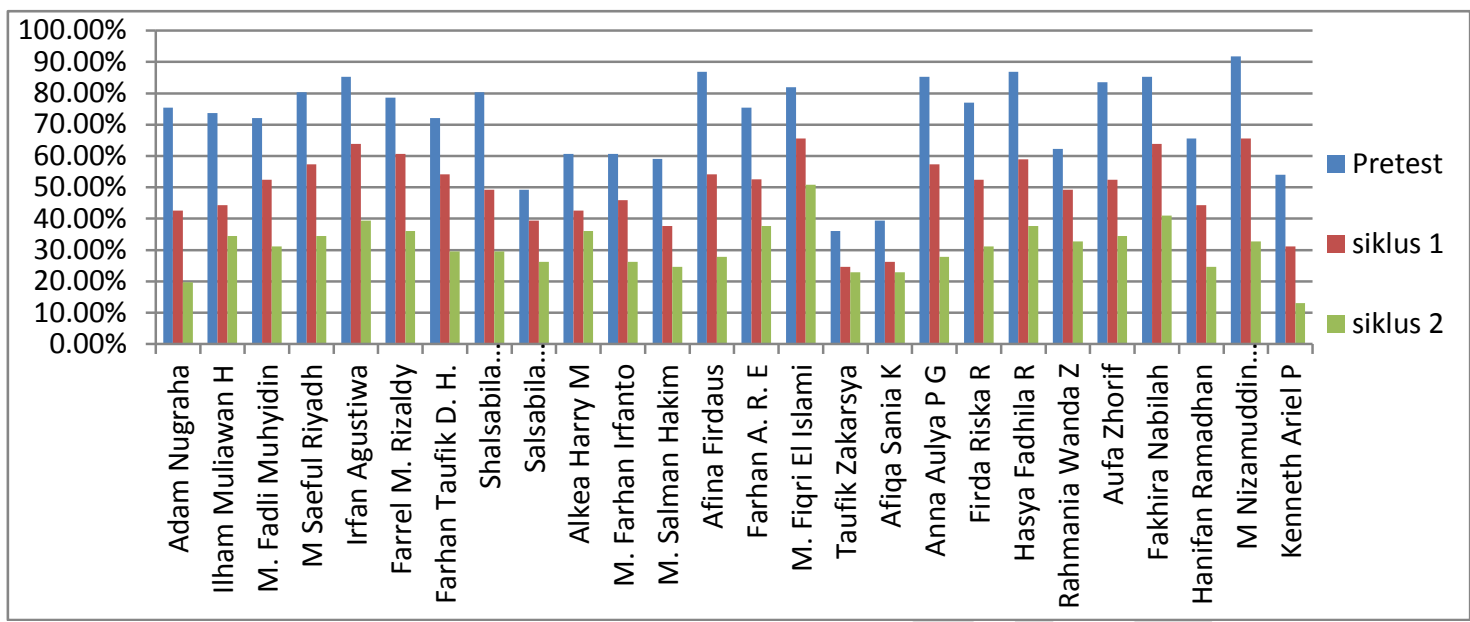

Grafik 7. Perbandingan Radikalisme Siswa pada Pre-test, Siklus 1 dan Siklus 2.

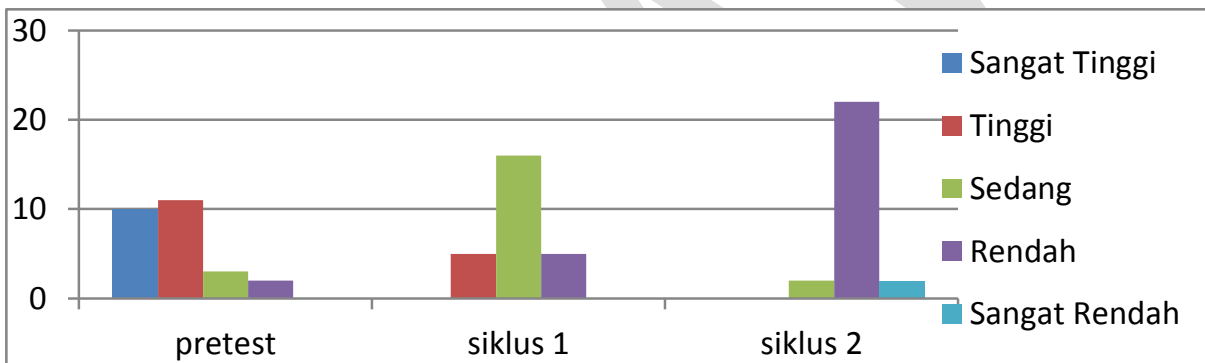

\section{Grafik 8. Perbandingan Jumlah Siswa Berdasarkan Kategorisasi Tingkat Radikalisme pada Pre-test, Siklus 1 dan Siklus 2.}

Disamping itu, dilihat dari jumlah siswa pada tiap kategorisasi tingkat radikalsime pun menunjukkan hasil yang positif. Perbandingan tingkat radikalisme siswa berdasarkan kategori pada pengukuran saat pretest, pengukuran radikalisme setelah siklus 1 dan pengukuran radikalisme setelah siklus 2 dapat dilihat pada Grafik 8. Pada grafik tersebut menunjukkan bahwa Jumlah siswa dengan tingkat radikaslime pada kategori sangat tinggi terus menurun. Pada pengukuran radikalisme saat pre-test terdapat 10 orang siswa dengan tingkat radikalisme kategori sangat tinggi. Pada pengukuran radikalisme siklus 1 dan 2 sudah tidak terdapat siswa dengan tingkat radikalisme dengan kategori sangat tinggi.
Begitupun untuk kategori radikalisme tinggi terus mengalami penurunan. Pada pengukuran pretest, terdapat 11 orang siswa dengan tingkat radikalisme tinggi. Sedangkan pada pengukuran radikalisme setelah siklus 1 jumlah siswa dengan tingkat radikalisme tinggi berkurang menjadi 5 orang siswa dan pada pengukuran radikalisme siswa setelah siklus 2 tidak ada lagi siswa dengan tingkat radikalisme tinggi.

Hasil sebaliknya terdapat pada kategori rendah dan sangat rendah yang jumlahnya terus bertambah dari tiap tahap pegukuran radikalisme. Pada kategori rendah, saat pengukuran pretest terdapat 2 orang dengan tingkat radikalisme rendah. Pada pengukuran setelah siklus 1 , 
jumlahnya betambah menjadi 5 orang dan pada pengukuran setelah siklus 2 jumlahnya meningkat menjadi 22 orang.

Sedangkan pada kategori sangat rendah, pada pengukuran radikalisme saat pretest dan setelah siklus satu tidak terdapat siswa dengan tingkat radikalisme sangat rendah, namun pada pengukuran setelah siklus 2 terdapat 2 orang siswa dengan tingkat radikalisme sangat rendah.

Lain halnya dengan perbandingan pada tingkat radikalisme sedang yang jumlahnya naik turun. Pada pengukuran radikalisme saat pre-test terdapat 3 orang dengan tingkat radikalisme sedang. Pada pengukuran radikalisme setelah siklus 1 jumlah nya meningkat menjadi 16 orang siswa sedangkan pada pengukuran setelah siklus 2 jumlah nya berkurang kembali menjadi 2 orang.

Berdasarkan uraian diatas, jumlah siswa dengan kategori radikalisme tinggi

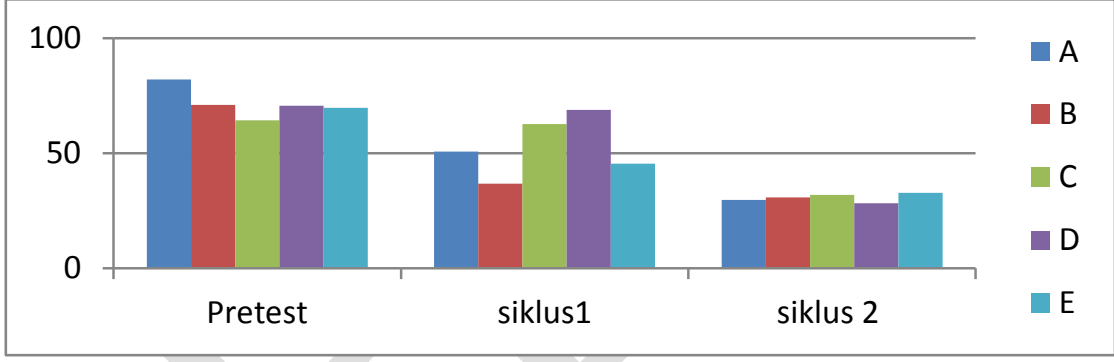

Grafik 9. Perbandingan Tingkat Radikalisme SIswa Berdasarkan Indikator pada Pretest, Siklus 1 dan Siklus 2.

Berdasarkan perbandingan indikator-indikator tersebut dari setiap tahapan pengukuran radikalisme, sebagaimana ditunjukkan pada grafik 9 , dapat dilihat bahwa pada pengukuran setelah siklus 1 dilakukan, terjadi perubahan yang signifikan pada indikator radikalisme A (fanatisme tehadap satu pendapat atau golongan), B (Mewajibkan muslim lain dalam menjalankan yang tidak wajib) dan E (mengafirkan orang lain) sedangkan pada indikator C (sikap keras yang tidak pada tempatnya dan kasar) dan D (berprasangka buruk) terjadi perubahan namun tidak signifikan. Sedangkan pada pengukuran radikalisme setelah siklus 2 didapati perubahan dan sangat tinggi terus berkurang dari setiap tahapan pengukuran dimulai dari pengukuran radikalisme saat pretest, siklus 1 hingga setelah siklus 2. Sedangkan untuk jumlah siswa dengan tingkat radikalisme pada kategori rendah dan sangat rendah terus bertambah.

Peneliti juga membandingkan perubahan yang terjadi dan mengelompokkannya kedalam indikatorindikator radikalisme seperti yang sebelumnya sudah disusun antara lain indikator A untuk fanatisme tehadap satu pendapat atau golongan, indikator B untuk mewajibkan muslim lain dalam menjalankan yang tidak wajib, indikator $\mathrm{C}$ untuk sikap keras yang tidak pada tempatnya dan kasar, indikator D untuk berprasangka buruk dan indikator $\mathrm{E}$ untuk mengafirkan orang lain. 


\section{KESIMPULAN}

$\begin{array}{lcr} & \text { Penerapan } & \text { materi deradikalisasi } \\ \text { melalui kajian } & \text { keagamaan } & \text { bisa } \\ \text { menanggulangi } & \text { radikalisme } & \text { di }\end{array}$
ekstrakurikuler keagamaan DKM Nurul Khomsah SMA Negeri 5 Bandung. Hal ini secara lebih rinci dapat disampaikan bahwa: (1) Kondisi awal siswa anggota ekstrakurikuler keagamaan DKM Nurul Khomsah SMA Negeri 5 Bandung berdasarkan hasil penelitian yang dilakukan peneliti mengenai tingkat radikalisme siswa sebelum diterapkan penelitian tindakan menunjukkan bahwa 11 orang siswa terindikasi radikal dengan kategori tinggi, bahkan terdapat 10 siswa terindikasi radikal dengan kategori sangat tinggi. Sedangkan 3 orang siswa terindikasi radikalisme sedang dan sisanya, 2 orang siswa terindikasi radikalisme rendah. secara umum pada kondisi awal tingkat radikaslime siswa anggota ekstrakurikuler keagamaan DKM Nurul Khomsah SMA Negeri 5 Bandung terindikasi radikal dengan kategori tinggi. (2) Pelaksanaan penerapan materi deradikalisasi melalui kajian keagamaan untuk menanggulangi radikalisme di ekstrakurikuler keagamaan DKM Nurul Khomsah SMA Negeri 5 Bandung dapat menanggulangi radikalisme di ekstrakurikuler tersebut. (3) Hasil penerapan materi deradikalisasi melalui kajian keagamaan untuk menanggulangi radikalisme di ekstrakurikuler keagamaan DKM Nurul Khomsah SMA Negeri 5 Bandung menunjukkan Perubahan signifikan. Hasil dari penerapan materi deradikalisasi memalui kajian keagamaan berhasil menanggulangi radikalisme di ekstrakurikuler tersebut dengan hasil akhir menunjukkan 2 orang siswa dengan tingkat radikalisme sedang, 22 orang siswa dengan tingkat radikalisme rendah dan 2 orang siswa lainnya dengan tingkat radikalisme sangat rendah. Pada hasil akhir tersebut, tingkat radikaslime siswa anggota ekstrakurikuler keagamaan DKM
Nurul Khomsah SMA Negeri 5 Bandung pada umumnya ada pada kategori rendah.

\section{DAFTAR PUSTAKA}

Arikunto, S. (2006). Classroom Action Research-CAR. In S. Arikunto, Suhardjono, \& Supardi, Penelitian Tindakan Kelas (pp. 1-42). Jakarta: Bumi Aksara.

Arikunto, S. (2009). Dasar-dasar Evaluasi Pendidikan. Jakarta: Bumi Aksara.

Bakti, A. S. (2015). Terorisme dan Tantangan Radikalisme Baru Dalam Sistem Kepemimpinan Nasional. Strategic Outlook: Jurnal Politik dan Keamanan Nasional, 36-21.

Burhani, A. N. (2001). Islam Dinamis. Jakarta: Kompas.

Felisiani, T. (2016, Februari 21). Polisi Temukan CD Pelatihan Militer dan Anak Panah di Rumah Terduga Teroris Cisauk. Retrieved April 13 , 2016, from Tribun Nasional: http://www.tribunnews.com/nasion al/2016/02/21/polisi-temukan-cdpelatihan-militer-dan-anak-panahdi-rumah-terduga-teroris-cisauk

Felisiani, T. (2016, Maret 16). Terduga Teroris yang Tewas di Poso Diduga Suku Uighur. Retrieved April 13, 2016, from Tribun Nasional:

http://www.tribunnews.com/nasion al/2016/03/16/terduga-terorisyang-tewas-di-poso-diduga-sukuuighur

Fiardini, R. (2016, Januari 14). Ledakan di Pos Polisi Sarinah Terdengar Hingga Gedung Sinarmas. Retrieved Januari 29, 2016, from Okezone.com:

http://news.okezone.com/read/2016 /01/14/338/1287887/ledakan-di-

pos-polisi-sarinah-terdengarhingga-gedung-sinarmas

Hibban, I. (2014). Radikalisme Agama Dalam Kajian Sosiologi. Jurnal Sosiologi Reflektif, 251-255. 
Hikam, M. A. (2015). Peran Kepemimpinan Visioner Dalam Rangka Menanggulangi Ancaman Radikalisme. Strategic Outlook: Jurnal Politik dan Pertahanan Nasional, 22-37.

Kuba, A., Saenong, F. F., Zuhri, S., Muid, A., Lodji, M., Hasan, H., et al. (2014). Modul Pelatihan Anti Radikal Terorisme Kepada Pimpinan dan Dosen. -: Tidak diterbitkan.

Muhamad, A. (2013). Agama dan Konflik Sosial. Bandung: Marja.

Munip, A. (2012). Menangkal Radikalisme Agama di Sekolah. Jurnal Pendidikan Islam , 160-181.

Qardhawi, Y. (2009). Islam Radikal. (H. Murtadho, Trans.) Pajang Laweyan: Era Adicitra Intermedia.

Suprihatiningsih. (2012). Spiritualitas Gerakan Radikalisme. Jurnal Ilmu Dakwah, 367-381.

Tomal, D. R. (2003). Action Research for Educators. Lanham: Scarecrow Press.

Wiratha, I. M. (2006). Pedoman Penulisan Usulan Penelitian, Skripsi dan Tesis. Yogyakarta: Penerbit Andi. 